\title{
Pradhan Mantri Jan Dhan Yojna and Financial Inclusivity: An Empirical Analysis
}

\author{
H. N. Shylaja \\ School of Management Studies, REVA University, Bengaluru - 560064, Karnataka, India
}

\begin{abstract}
A financial system which is inclusive is deemed a pre requisite for sustainable development and growth which encompasses all sections of the society. Financial inclusivity has been a top policy prerogative and several initiatives launched to ring in financial inclusion. From the nationalization of Banks in late 1960s till the very recent small payment banks and PMJDY, multiple initiatives have been introduced to ensure $100 \%$ inclusion. The present study has been conducted to know the progress made through the much-coveted PMJDY scheme of the government. Also, an attempt is made to know from the business correspondents, their experiences both pre- and post-implementation of PMJDY. The study is based on both primary and secondary data. While the secondary data has been collected from the website of PMJDY, primary data is collected from the business correspondents. The secondary data is analysed using CAGR, paired two sample $t$ test is used to analyze the primary data. It has been found that there is a significant improvement in the number of households covered through PMJDY and there has been a significant improvement in usage of financial services as is reflected by the increase in the amount which is deposited in BSBDA accounts. Also, as per the experiences of business correspondents there is a significant improvement in the banking habits of newly included. The implication of the study is that it gives indications to the policy makers and the practitioners about the course of action to be taken to increase the usage of the financial services now that there has been a significant improvement in accessibility.
\end{abstract}

Keywords: PMJDY, Financial Inclusion, Access and Usage of Banking Services, Economic Growth, Business Correspondents, Inclusive Growth

\section{Introduction}

Financial exclusion is a situation where a certain section of the society is not able to have access to the suitable financial products and services at an affordable cost which otherwise are available to the affluent section of the society. With the objective of bringing such financially excluded section of the society under the ambit of being able to access financial services, a lot of initiatives starting from nationalization of banks till the very recent PMJDY have been introduced from time to time. Financial Inclusion (FI) does not merely mean access to credit for the poor, but also other financial services such as Insurance, pension, remittance, mutual funds, etc. delivered at affordable, though market driven costs. Opening a no-frills account is just a beginning to a continuous process of providing banking and financial services. Once the first step of safety of savings is achieved, the poor require access to schemes and products which allow their savings to grow at rates which provide them growth beyond mere inflation protection.

Pradhan Mantri Jan Dhan Yojna is an initiative which was introduced in the year 2014, which is a comprehensive financial inclusion plan pan India with the sole objective of covering all hitherto excluded households into the purview of banking services and thereby ensuring that all get access and will be able to use the benefits and facilities provided by the formal 
banking sector. This scheme envisages the provision of accessing and using the formal banking services by all citizens within a certain reasonable distance.

Other than the Universal access to banking facilities with at least one basic banking account for every household the scheme envisages financial literacy, access to credit, insurance and pension facility, No minimum balance requirement, Interest on deposit, a life insurance cover of Rs. 30,000, inbuilt accident insurance cover of 1 lakh easy transfer of money across the country and direct benefit transfer to their accounts from the centre and the state government and other agencies are the facilities that one would get. Being planned to be executed in two phases, the first starting from the $15^{\text {th }}$ August 2014 to $14^{\text {th }}$ of August 2015 and the second phase from $15^{\text {th }}$ August 2015 to $14^{\text {th }}$ August 2018, there are a lot of hopes that this scheme would bring in $100 \%$ inclusion and ensure that all who hitherto were excluded would participate in the mainstream financial sector. The scheme will be rolled out by utilizing the existing infrastructure of institutions like post offices, through PPP. The existing system of BCs would be restructured and strengthened and thereby the model made more viable. Expansion of bank branches and the ATMs, creation of swabhimann villages, mapping the sub service areas, coverage of SSAs, focusing more on urban financial inclusion, strengthening the existing model of $\mathrm{BCs}$, mobile banking and national unified USSD platforms are some of the implementation plans of PMJDY.

\section{Review of Literature}

Literature review suggests that most of the operational definitions about FI or exclusion is either context specific which is developed out of country specific problems and also the economic and social conditions. Specific dimensions of FI or exclusion play a very important role from the perspective of development of public policy. However, a careful look into the development of definitions clearly reveals that during the development stages, the focus was largely on availability of physical access which lately covers the access to, knowledge about the products and usage of the same.

http://www.informaticsjournals.com/index.php/sdmimd | Vol 12| Issue 1| March 2021
As per the definition given by the Committee on FI in India, Rangarajan (2008).

"...FI is the process of ensuring access to financial services and timely and adequate credit where needed by vulnerable groups such as weaker sections and low income groups at an affordable cost." (Report of the Committee on FI in India, 2008)

Aynsely (2010), in the study opines that there are three key aspects for the definition of FI: the access to financial services and products, financial capability, and financial literacy. However, it has been observed time over and again that most of the definitions focus more on emphasize on the indicators than the other elements.

Kumar (2012), has observed that in an emerging economy like India, FI agenda has gained momentum of late. And the problem of FE is more prevalent in rural and less populated regions when compared to urban and developed areas. Based on the study conducted it has been found that there has been a high growth of branches in regions which had less density of branches initially. Also it has been found that the regions with high income has experienced higher branch growth rate. They conclude the study by making an observation that there has been a evidence of positive impact of different inclusion initiatives taken by the regulatory bodies.

Singh \& Tandon (2013) highlighted that in the efforts towards FI, the banks have to restructure their business policies towards FI of low-income groups and treat the entire process of FI as both a business opportunity and a social obligation.

CRISIL Inlcusix report, (2013) in the Inclusix report on Indian FI status bought out the information that there is an increase in the FI score from 35.4 in 2009 to 42.8 in the year 2012 which clearly indicates that the status of FI in the country has definitely improved.

In their study, Paramasivan and Ganeshkumar (2013) concluded that branch density has had a significant impact on financial inclusion. Julie (2013) opined that there is a strong positive relationship between financial inclusion and economic growth in Kenya 
Mishra (2015) opined that FI targets to bring all unbanked under umbrella of formal financial sector would certainly enhance their social and economic conditions and help the poor to escape from the vicious circle of poverty. Financial inclusive education will make the vulnerable section of the society to be aware of public policies, FI mission, rules and regulations regarding various aspects of financial services. It is also opined that awareness camps needs to be organized to make poor people aware of banking facilities.

Barua, Kathuria \& Malik (2016), opine that in India, FI is at the heart of the policy agenda and the focus has shifted to not only savings but also credit, insurance and pension. With the intervention of effective and suitable technology measures, the delivery of financial resources could be ensured to the households.

Pal (2016), opines that strengthening of micro finance, business facilitator and $\mathrm{BC}$ can contribute in easy access to banking services especially for the rural poor. Also, a greater number of rural banks branches should be established for rural poor along with enhancing financial awareness.

Verma \& Garg (2016) in their study opine that lack of finance and financial illiteracy are few of the important reasons as to why people, particularly the rural folk stayed out of the financial system. They conclude their study by saying that though there is a lot of work yet to be done to bring financial inclusion in the real sense, the encouraging fact is that majority of the respondents of their study are aware of the PMJDY.

Iqbal \& Sami (2017), in their article suggest that the problems of lack of accessible, affordable and appropriate financial services which were always the inherent problems of India, has to be tackled by increasing the financial access which thereby would boost not only the financial condition but also the standard of life of poor.

Kamboj (2014) in the study state that India has indeed witnessed a quick progress in financial inclusion though there is still a long way to go to achieve the dream of universal financial inclusion. They also state that there is a tremendous progress made after the implementation of Pradhan Mantri Jan Dhan Yojana in terms of opening of bank deposits.

Rajasekaran (2018) in their study state that for overcoming the difficulties in reachability, the model of $\mathrm{BC} / \mathrm{BF}$ has been introduced. BSBDA and DBT has resulted in increased number of financially excluded into the system. The author opines that the banks and the government should take additional efforts and initiatives to ensure financial literacy and thereby encourage more and more people to use financial services.

Most of the studies conducted on various perspectives of financial inclusion bring out the fact that there has been a significant increase in the number of people who are financially included. The studies also suggest that there also has been a significant rise in the accessibility of financial services. The studies also bring out the fact that one of the recent initiatives to boost Financial inclusion, PMJDY has acted as a catalyst and boosted the reachability of banks to the remotest villages. Also there are certain studies which have bought out the contribution of $\mathrm{BC} / \mathrm{BF}$ model. This study is conducted with the objective of analyzing the progress made post implementation of PMJDY and also to find from the grass roots level beneficiaries, their perspective both post and pre PMJDY.

\section{Objectives of the Study}

The intent of the study is to analyze the progress made in terms of expansion of banking services through the PMJDY. Having increased the banking accessibility, the banks have further gone near to the last mile customer through both branch and branches models. An attempt is also made to understand from the business correspondents' perspective, their observation about the beneficiaries' banking habits both before and after the PMJDY. With the observations made from the perspective of the BCs, there are certain suggestions made to ensure that model can be made even more benefitting the banking landscape. 


\section{Research Methodology}

The study is based on both primary as well as the secondary data. The primary data is collected with the help of a structured close ended questionnaire using which data is collected from BCs who have a minimum of two years of experience prior implementation of PMJDY. The first set of data is collected just before the implementation of PMJDY between September 2014 to December 2014 while the second set of data is collected from the same BCs, after the implementation of PMJDY between July to August in 2018. The rationale for selecting the $\mathrm{BCs}$ for seeking their opinion is that since they are the ones in close proximity with the last mile customers, they would know their banking practices, issues and challenges faced by them.

The secondary data is collected from PMJDY website for further analysis.

The CAGR is calculated for evaluating the progress in terms of financial inclusion wherein the two samples of $\mathrm{BCs}$ responses are analyzed using two sample paired $\mathrm{t}$ test.

The rationale for using the two-sample paired t test is because we are comparing two samples, the data which is being collected from the same set of respondents twice. Here an attempt is made to know the differences recorded in the posed questions.

\section{Findings of the Study}

With the mission mode introduction and implementation of the PMJDY across the country, the kind of growth in terms of the number of bank branches, number of beneficiaries who got access to banking services, growth in the number of deposit accounts, growth in the money deposited in the deposit accounts and such other things, has increased manifold. Table 1 presents the progress made in terms of PMJDY since its launch in the year 2014.

\subsection{Report on Progress in PMJDY since the Launch in August 2014}

Table 1 gives detailed information related to the progress in the Pradhan Mantri Jan Dhan Yojana since the date it was incepted.

With the launch of the much-coveted Pradhan Mantri Jan Dhan Yojana, there has been an increase in the number of those benefitted particularly in the rural and the semi urban section by about $26 \%$ over the last four years' time. The number has seen a significant improvement by over $27 \%$ in the urban and metro centres too. Though the average growth in the country is over $26 \%$ across all regions, there has been a significant increase in the money deposited in such accounts by over $63 \%$. Also there has been a growth in the number of rupay cards issued to the beneficiaries by over $22 \%$ from 2015 to 2019 .

\subsection{Status of Geographical Distribution of Beneficiaries, Balance in Beneficiary Account and the Number of Rupay Cards}

Table 2 gives details of the number of beneficiaries across all sections and across all states too. There has been a considerable increase in the number of

Table 1. Details of the progress in PMJDY since the launch in August 2014

\begin{tabular}{|l|c|c|c|c|c|c|}
\hline & $\mathbf{2 0 1 5}$ & $\mathbf{2 0 1 6}$ & $\mathbf{2 0 1 7}$ & $\mathbf{2 0 1 8}$ & $\mathbf{2 0 1 9}$ & CAGR \% \\
\hline $\begin{array}{l}\text { Number of Beneficiaries at rural/semi } \\
\text { urban center bank branches (in Crores) }\end{array}$ & $8,67,72,337$ & $13,17,07,034$ & $16,86,63,484$ & $19,01,89,607$ & $21,68,79,196$ & $25.73 \%$ \\
\hline $\begin{array}{l}\text { Number of Beneficiaries at urban and } \\
\text { metro center bank branches (in Crores) }\end{array}$ & $5,85,95,703$ & $8,25,68,440$ & $11,30,14,787$ & $13,23,10,158$ & $15,10,64,059$ & $26.71 \%$ \\
\hline Number of Total Beneficiaries (in Crores) & $14,53,68,040$ & $21,42,75,474$ & $28,16,78,271$ & $32,24,99,765$ & $36,79,43,255$ & $26.13 \%$ \\
\hline Deposit in Accounts (Rs. In lakh) & $14,64,064.61$ & $35,67,200.72$ & $62,97,242.81$ & $80,67,482.19$ & $1,02,41,542.78$ & $62.63 \%$ \\
\hline $\begin{array}{l}\text { Number of Rupay Card issued to } \\
\text { beneficiaries (in Crores) }\end{array}$ & $12,99,17,010$ & $17,75,29,672$ & $21,99,38,757$ & $24,26,68,879$ & $29,14,70,537$ & $22.39 \%$ \\
\hline
\end{tabular}

Source: Progress Report, PMJDY, as on 28/08/2019 
Table 2. Details of beneficiaries, balance in beneficiary account and rupay cards issued

\begin{tabular}{|c|c|c|c|c|c|c|}
\hline S.No & State & $\begin{array}{l}\text { Beneficiaries at } \\
\text { rural/semi-urban } \\
\text { centre bank } \\
\text { branches }\end{array}$ & $\begin{array}{l}\text { Beneficiaries at } \\
\text { urban/metro centre } \\
\text { bank branches }\end{array}$ & Total Beneficiaries & $\begin{array}{l}\text { Balance in } \\
\text { beneficiary accounts } \\
\text { (in crore) }\end{array}$ & $\begin{array}{c}\text { No. of RuPay } \\
\text { cards issued to } \\
\text { beneficiaries }\end{array}$ \\
\hline 1 & Andaman \& Nicobar Islands & 33,127 & 16,764 & 49,891 & 23.63 & 41,225 \\
\hline 2 & Andhra Pradesh & $50,68,433$ & $51,57,489$ & $1,02,25,922$ & $1,973.41$ & $83,17,274$ \\
\hline 3 & Arunachal Pradesh & $1,97,380$ & $1,23,486$ & $3,20,866$ & 121.53 & $2,76,650$ \\
\hline 4 & Assam & $1,20,11,645$ & $38,07,151$ & $1,58,18,796$ & $3,704.08$ & $1,22,88,615$ \\
\hline 5 & Bihar & $2,66,68,968$ & $1,55,24,537$ & $4,21,93,505$ & $10,845.42$ & $3,44,89,653$ \\
\hline 6 & Chandigarh & 45,245 & $2,10,263$ & $2,55,508$ & 113.24 & $1,87,574$ \\
\hline 7 & Chhattisgarh & $93,80,789$ & $51,67,462$ & $1,45,48,251$ & $3,245.11$ & $1,03,92,069$ \\
\hline 8 & Dadra \& Nagar Haveli & 98,474 & 24,888 & $1,23,362$ & 53.13 & 82,724 \\
\hline 9 & Daman \& Diu & 24,529 & 29,850 & 54,379 & 21.39 & 42,154 \\
\hline 10 & Delhi & $5,50,677$ & $39,61,857$ & $45,12,534$ & $1,881.20$ & $38,35,774$ \\
\hline 11 & Goa & $1,20,981$ & 42,710 & $1,63,691$ & 94.31 & $1,23,342$ \\
\hline 12 & Gujarat & $75,00,648$ & $70,17,679$ & $1,45,18,327$ & $4,519.14$ & $1,19,81,540$ \\
\hline 13 & Haryana & $36,67,293$ & $36,86,471$ & $73,53,764$ & $3,362.44$ & $61,77,544$ \\
\hline 14 & Himachal Pradesh & $11,02,341$ & $1,47,554$ & $12,49,895$ & 671.47 & $9,91,602$ \\
\hline 15 & Jammu \& Kashmir & $19,51,633$ & $3,23,795$ & $22,75,428$ & 969.72 & $17,26,352$ \\
\hline 16 & Jharkhand & $93,85,105$ & $35,62,106$ & $1,29,47,211$ & $3,504.14$ & $1,03,08,318$ \\
\hline 17 & Karnataka & $81,91,223$ & $65,64,004$ & $1,47,55,227$ & $3,793.28$ & $1,02,95,417$ \\
\hline 18 & Kerala & $20,63,417$ & $21,43,935$ & $42,07,352$ & $1,343.19$ & $30,08,522$ \\
\hline 19 & Lakshadweep & 4,417 & 986 & 5,403 & 8.56 & 5,164 \\
\hline 20 & Madhya Pradesh & $1,49,06,183$ & $1,71,40,444$ & $3,20,46,627$ & $5,355.46$ & $2,50,74,815$ \\
\hline 21 & Maharashtra & $1,29,19,449$ & $1,32,40,099$ & $2,61,59,548$ & $6,274.75$ & $1,87,14,489$ \\
\hline 22 & Manipur & $4,05,026$ & $5,26,437$ & $9,31,463$ & 196.31 & $7,11,301$ \\
\hline 23 & Meghalaya & $3,88,792$ & 70,534 & $4,59,326$ & 193.9 & $3,21,800$ \\
\hline 24 & Mizoram & $1,19,838$ & $1,88,956$ & $3,08,794$ & 101.45 & 85,023 \\
\hline 25 & Nagaland & $1,22,017$ & $1,72,458$ & $2,94,475$ & 60.14 & $2,43,136$ \\
\hline 26 & Odisha & $1,09,54,745$ & $39,87,087$ & $1,49,41,832$ & $4,641.89$ & $1,23,74,426$ \\
\hline 27 & Puducherry & 69,628 & 85,979 & $1,55,607$ & 41.49 & $1,16,195$ \\
\hline 28 & Punjab & $39,62,786$ & $29,27,628$ & $68,90,414$ & $2,550.24$ & $55,94,069$ \\
\hline 29 & Rajasthan & $1,56,00,208$ & $1,07,15,367$ & $2,63,15,575$ & $7,949.09$ & $2,06,01,442$ \\
\hline 30 & Sikkim & 66,259 & 27,468 & 93,727 & 40.52 & 71,164 \\
\hline 31 & Tamil Nadu & $48,75,623$ & $55,86,950$ & $1,04,62,573$ & $1,986.13$ & $86,16,104$ \\
\hline 32 & Telangana & $49,02,827$ & $48,31,100$ & $97,33,927$ & $1,664.41$ & $79,60,666$ \\
\hline 33 & Tripura & $6,25,508$ & $2,57,582$ & $8,83,090$ & 674.81 & $6,87,368$ \\
\hline 34 & Uttar Pradesh & $3,42,78,604$ & $2,47,33,606$ & $5,90,12,210$ & $19,275.18$ & $4,76,33,374$ \\
\hline 35 & Uttarakhand & $15,71,194$ & $9,58,875$ & $25,30,069$ & $1,187.75$ & $20,08,987$ \\
\hline 36 & West Bengal & $2,33,63,233$ & $1,19,89,709$ & $3,53,52,942$ & $12,451.66$ & $2,91,03,974$ \\
\hline 37 & Total & $21,71,98,245$ & $15,49,53,266$ & $37,21,51,511$ & $1,04,893.56$ & $29,44,89,846$ \\
\hline
\end{tabular}

Source: PMJDY progress report, 2019 
beneficiaries who have got benefitted since inception of the initiative across all geographical sections. There also has been a considerable improvement in not only in the amount deposited in beneficiary account but also in the number of rupay cards distributed.

\subsection{Status of the Household Coverage Across Different States}

Table 3 gives the details related to the total allotted wards and the total number of covered households across the different states in the country. The table also gives information related to the household coverage in terms of percentage.

Clearly with the concerted efforts of both the banks and the government, there has been $100 \%$ household coverages other than few states, in terms of banking accessibility provision. This clearly shows that the concerned authorities have put serious efforts to reach out to all households across their allotted regions by employing different strategies. This is the reason for considerable decrease in the percentage of unbanked population in the country which has dropped to $19 \%$ in the year 2017 (World bank report, 2017) from 46\% in the year 2011 (NSSO 11 ${ }^{\text {th }}$ round report).

\subsection{The Field Experience of Business Correspondents}

The Business Correspondent model or Bank Mitr model of financial inclusion has been given lot of importance in the PMJDY as could be seen in the implementation plans and the strategies devised. It is in this context that the following study is made. The present section of the study focuses on knowing the experiences of the $\mathrm{BCs}$ post the implementation of PMJDY. Only those $\mathrm{BCs}$ who have more than four years of experiences are selected. A set of 26 key questions were designed for which the answers were sought from the selected BCs. The BCs were interviewed in two phases. Initially, they were interviewed during the first phase when the PMJDY was just announced and the work had just started rolling. Secondly, they were interviewed almost two years after the implementation of PMJDY and their answers recorded. The same is presented in the following section.
Table 3. Details of household coverage of Basic Bank Accounts across different states

\begin{tabular}{|c|c|c|c|}
\hline State Name & $\begin{array}{c}\text { Allotted } \\
\text { Wards-SSAs }\end{array}$ & $\begin{array}{l}\text { Covered } \\
\text { Households }\end{array}$ & $\begin{array}{c}\text { Household } \\
\text { Coverage \% }\end{array}$ \\
\hline JAMMU \& KASHMIR & 604 & $3,56,295$ & $99.71 \%$ \\
\hline Himachal Pradesh & 2,489 & $12,98,191$ & $100.00 \%$ \\
\hline Punjab & 6,743 & $47,46,147$ & $100.00 \%$ \\
\hline Chandigarh & 136 & $1,93,876$ & $100.00 \%$ \\
\hline Uttarakhand & 2,769 & $11,36,431$ & $100.00 \%$ \\
\hline Haryana & 4,870 & $45,96,617$ & $100.00 \%$ \\
\hline DELHI & 266 & $26,96,322$ & $100.00 \%$ \\
\hline Rajasthan & 14,169 & $1,14,63,959$ & $99.99 \%$ \\
\hline Uttar Pradesh & 37,424 & $3,11,59,992$ & $100.00 \%$ \\
\hline Bihar & 14,640 & $1,72,81,831$ & $100.00 \%$ \\
\hline Sikkim & 175 & $1,31,086$ & $100.00 \%$ \\
\hline Arunachal Pradesh & 236 & $1,97,861$ & $100.00 \%$ \\
\hline Nagaland & 413 & $3,33,762$ & $99.92 \%$ \\
\hline Manipur & 576 & $5,13,359$ & $99.76 \%$ \\
\hline Mizoram & 228 & $1,81,946$ & $99.92 \%$ \\
\hline Tripura & 767 & $7,55,041$ & $100.00 \%$ \\
\hline Meghalaya & 539 & $4,77,182$ & $100.00 \%$ \\
\hline Assam & 4,925 & $50,11,228$ & $99.96 \%$ \\
\hline West Bengal & 13,248 & $1,92,61,587$ & $100.00 \%$ \\
\hline Jharkhand & 5,147 & $54,38,679$ & $100.00 \%$ \\
\hline ORISSA & 7,962 & $74,32,140$ & $99.85 \%$ \\
\hline Chhattisgarh & 6,197 & 51,89795 & $99.98 \%$ \\
\hline Madhya Pradesh & 18,410 & $1,47,39,932$ & $100.00 \%$ \\
\hline Gujarat & 9,831 & $1,17,09,247$ & $100.00 \%$ \\
\hline DAMAN \& DIU & 24 & 22,528 & $100.00 \%$ \\
\hline $\begin{array}{l}\text { DADRA \& NAGAR } \\
\text { HAVELI }\end{array}$ & 35 & 59,908 & $100.00 \%$ \\
\hline Maharashtra & 17,722 & $1,63,74,030$ & $100.00 \%$ \\
\hline Andhra Pradesh & 11,592 & $1,18,55,366$ & $100.00 \%$ \\
\hline Karnataka & 11,645 & $1,11,75,204$ & $99.97 \%$ \\
\hline Goa & 396 & $3,31,457$ & $100.00 \%$ \\
\hline Lakshadweep & 29 & 10,189 & $100.00 \%$ \\
\hline Kerala & 5,582 & $45,85,375$ & $100.00 \%$ \\
\hline Tamil Nadu & 19,987 & $1,43,53,794$ & $100.00 \%$ \\
\hline PUDUCHERRY & 177 & $2,52,105$ & $100.00 \%$ \\
\hline $\begin{array}{l}\text { ANDAMAN \& } \\
\text { NICOBAR }\end{array}$ & 51 & 67,287 & $100.00 \%$ \\
\hline Telangana & 6,193 & $52,23,218$ & $100.00 \%$ \\
\hline
\end{tabular}

Source: Progress Report, PMJDY, 28/08/2019 


\subsubsection{Beneficiaries-Before and After PMJDY: An Observation by $B C$}

Since its inception in 2006, a lot of importance has been given to the Business Correspondent model of financial inclusion. Since then, to ensure that the model works as expected, various reforms and impetus has been given. At the outset it appears that there is an improvement in the availability of banking services to hitherto areas where there were no banking services earlier. With an objective of making an assessment of how improved are the banking services, the present research has been conducted. For this a set of $100 \mathrm{BCs}$ who have more than four years of experience working as BCs has been selected and administered a structured questionnaire and their responses recorded twice, first time being before the implementation of the PMJDY yojana and the second time being three years after the implementation of the same.

Paired two sample $t$ test is run to find if there exists any difference between the means of two samples. While the data regards to the pre PMJDY is considered as one sample, the data regards to the post PMJDY is considered to be the second sample. Also, their means calculated and the hypothesis is tested.

The following section examines the BCs perspective and the hypothesis tested across different parameters.

\subsubsection{Dependency on Money Lenders}

Ha: The mean difference of pre and Post PMJDY samples with reference to dependency on local money lenders is not zero

Ho: The mean difference of pre and Post PMJDY samples with reference to dependency on local money lenders is zero

The non-availability of funds to meet their various requirements drives the people towards availing the loan from that source which is easily available. Availability of such informal sources of finance in the vicinity drives the unbanked to approach these money lenders at the time of need. But it is also a fact that once they are in the clutches of such money lenders, it would be very difficult for them to get out the interest trap.
With the launch of PMJDY and the associated DBT and other such initiatives, there appears to be a certain decrease in the number of people approaching money lenders.

We could see that the PMJDY initiative of FI has a very positive impact on bringing down the dependency of villagers on the local money lenders for their financial requirements. Upon running the paired two sample $t$ test for means, with a significant value less than 0.05 as shown in Table 4, it is statistically proven that there has been a statistically significant difference in the means of pre and post PMJDY dependency of the excluded on the money lenders. This clearly indicates that the people now are slowly facing towards formal sources of finance than the informal sources. Thus, the null hypothesis is rejected that the means across the two samples is equal.

\subsubsection{Availability of Loan When Needed}

Ha: The mean difference of pre and Post PMJDY samples with reference to availability of loan when needed with complexities is not zero

Ho: The mean difference of pre and Post PMJDY samples with reference to availability of loan when needed with complexities is zero

Table 4. Details of the t-test results of beneficiaries and their dependence on the money lenders

\begin{tabular}{|l|c|c|}
\hline \multicolumn{3}{|c|}{ t-Test: Paired Two Sample for Means } \\
\hline Mean & Pre PMJDY & Post PMJDY \\
\hline Variance & 3.06 & 4.64 \\
\hline Observations & 0.966060606 & 0.293333 \\
\hline Pearson Correlation & 100 & 100 \\
\hline Hypothesized Mean Difference & -0.110814032 & \\
\hline df & 0 & \\
\hline t Stat & 99 & \\
\hline $\mathbf{P}(T<=t)$ one-tail & -13.46266961 & \\
\hline $\mathbf{t}$ Critical one-tail & $2.1147 \mathrm{E}-24$ & \\
\hline $\mathbf{P}(\mathrm{T}<=\mathrm{t})$ two-tail & 1.660391156 & \\
\hline $\mathbf{t}$ Critical two-tail & $\mathbf{4 . 2 2 9 4 E - 2 4}$ & \\
\hline
\end{tabular}

Source: Authors' own calculation 
Difficult, sophisticated and technical terminologies used by the banking officers was one of the factors which had kept the underprivileged section of the society out of accessing the banking services, particularly the loan products. Non accessibility to the banking services was also one of the factors which kept the unbanked away from banks for a long time. Post the FI initiatives and also initiatives such as PMJDY and the BC model, there has been an increase in the number of bank branches, and also the availability of bank services through the BCs at their doorstep. This has led to an increase in the number of people approaching banks for loans in times of need. The BCs were asked if they could see any difference in the level of availability of loans as perceived by the beneficiaries and the results of the test are presented in Table 5.

Upon running the paired two sample t test for means, the significant value is less than 0.05 , we reject the null hypothesis and accept the alternate hypothesis and it is concluded that there is statistically significant difference between the means of Pre and Post PMJDY samples of availability of banking services without much hassles. This points out that there is a statistically significant improvement in the availability of loan in time of need. Therefore, we conclude that PMJDY has impacted the ease of availability of loan to those who need it without much hassles.

Table 5. Details of the t-test results of availability of loan when needed

\begin{tabular}{|l|l|l|}
\hline \multicolumn{3}{|c|}{ t-Test: Paired Two Sample for Means } \\
\hline & PRE PMJDY & POST PMJDY \\
\hline Mean & 2.67 & 3.64 \\
\hline Variance & 0.768787879 & 1.040808081 \\
\hline Observations & 100 & 100 \\
\hline Pearson Correlation & -0.021229221 & \\
\hline Hypothesized Mean Difference & 0 & \\
\hline df & 99 & \\
\hline $\mathbf{t}$ Stat & -7.136259049 & \\
\hline $\mathbf{P}(\mathbf{T}<=t)$ one-tail & $8.06253 \mathrm{E}-11$ & \\
\hline $\mathbf{t}$ Critical one-tail & 1.660391156 & \\
\hline $\mathbf{P}(\mathbf{T}<=\mathbf{t})$ two-tail & $1.61251 \mathrm{E}-10$ & \\
\hline $\mathbf{t}$ Critical two-tail & 1.984216952 & \\
\hline
\end{tabular}

Source: Authors' own calculation

http://www.informaticsjournals.com/index.php/sdmimd | Vol 12| Issue 1| March 2021

\subsubsection{Saving Habits Amongst Beneficiaries}

Ha: The mean difference of pre and Post PMJDY samples with reference to improvement in saving habits of people is not zero.

Ho: The mean difference of pre and Post PMJDY samples with reference to improvement in saving habits of people is zero.

With non-availability of banking services, there was a significant savings which was out of reach to the formal banking system. With increase in the number of bank branches as a result of financial inclusion initiatives and the accessibility of banks through the $\mathrm{BCs}$, it looks like there is a slight improvement in the number of people depositing their savings with banks. Through the questionnaire, information is collected about the savings habit of the beneficiaries both pre and post PMJDY and the results are given in Table 6.

Increased financial awareness and widespread financial literacy programs and the added riders post PMJDY, it appears that there has been a slight improvement in the saving habits of people when it comes to banking. Upon running the paired two sample $t$ test for the pre and post PMJDY samples with reference to improvements in saving habits if any, it is statistically proven that there is statistically significant difference between the means

Table 6. Details of the t-test results of improvement in the saving habits of beneficiaries

\begin{tabular}{|c|c|c|}
\hline \multicolumn{3}{|c|}{ t-Test: Paired Two Sample for Means } \\
\hline & PRE PMJDY & POST PMJDY \\
\hline Mean & 1.61 & 3.67 \\
\hline Variance & 0.785757576 & 1.273838384 \\
\hline Observations & 100 & 100 \\
\hline Pearson Correlation & 0.122468431 & \\
\hline Hypothesized Mean Difference & 0 & \\
\hline df & 99 & \\
\hline t Stat & -15.29266921 & \\
\hline$P(T<=t)$ one-tail & 4.05945E-28 & \\
\hline t Critical one-tail & 1.660391156 & \\
\hline$P(T<=t)$ two-tail & 8.1189E-28 & \\
\hline t Critical two-tail & 1.984216952 & \\
\hline
\end{tabular}

Source: Authors' own calculation 
of Pre and Post PMJDY samples as the significant value is less than 0.05 as shown in Table 6. Thus, we could conclude that there is a definitive improvement in the savings habits of people as per the observations made by the business correspondents who directly interact with the individuals.

\subsubsection{Beneficiaries and the Usage of Banking Services}

Ha: The mean difference of pre and Post PMJDY samples with reference to increase in the number of people availing banking services is not zero.

Ho: The mean difference of pre and Post PMJDY samples with reference to increase in the number of people availing banking services is zero.

With the mission mode launch of PMJDY and the widespread publicity about the benefits of having an account under PMJDY, there has been a sudden increase in the number of accounts opened across all the banks in the country. However, mere opening of account does not ensure the usage of banking services unless the accounts are operated. What is equally important is to get these people to actually operate their accounts too. However, the access to such BSBDA accounts is deemed the gateway for gamut of other banking services. With the objective of knowing if there is any improvement in the number of people using the banking services post PMJDY when compared to pre PMJDY, the following question was asked, the results being presented in Table 7 .

Paired two sample tests was performed on the two samples to know if there was any increase or improvement in the usage of banking services and upon running the test it is found that the significant value is less than 0.05 , and therefore there is no evidence to reject the alternate hypothesis. Therefore, we reject the null hypothesis and accept the alternate hypothesis and thereby it can be concluded that there is statistically significant difference between the means of Pre and Post PMJDY samples. Thus, we could conclude that there is a statistically significant improvement in the banking habits of beneficiaries.

\subsubsection{Beneficiaries and the Number of Transactions at the Hand-held Machines of the BCs}

Ha: The mean difference of the pre and post PMJDY samples with reference to the transactions both deposit and withdrawals conducted at the BC points is not zero.

Ha: The mean difference of the pre and post PMJDY samples with reference to the transactions both deposit and withdrawals conducted at the BC points is zero.

Providing the banking services at the doorstep of every villager at their village and thereby promoting financial inclusivity was one of the objectives of FI. In an attempt to take the bank to the end user, the BCs were provided with the hand-held device, using which he would provide the banking service to the beneficiaries in his or her village. Initially the number of transactions which a $\mathrm{BC}$ would register was less which started to improve gradually with the increased awareness and financial literacy. In an attempt to compare the number of transactions held before and after PMJDY, a question was designed results of which are presented in Table 8.

Paired two sample tests was performed on the two samples to know if there was any improvement in the

Table 7. Details of the t-test results of beneficiaries and the usage of banking services

\begin{tabular}{|l|c|c|}
\hline \multicolumn{3}{|c|}{ t-Test: Paired Two Sample for Means } \\
\hline Mean & PRE PMJDY & POST PMJDY \\
\hline Variance & 3.06 & 4.64 \\
\hline Observations & 0.966060606 & 0.293333 \\
\hline Pearson Correlation & 100 & 100 \\
\hline Hypothesized Mean Difference & -0.110814032 & \\
\hline df & 0 & \\
\hline $\mathbf{t}$ Stat & 99 & \\
\hline $\mathbf{P}(\mathrm{T}<=\mathrm{t})$ one-tail & -13.46266961 & \\
\hline $\mathbf{t}$ Critical one-tail & $2.1147 \mathrm{E}-24$ & \\
\hline $\mathbf{P}(\mathrm{T}<=\mathrm{t})$ two-tail & 1.660391156 & \\
\hline $\mathbf{t}$ Critical two-tail & $4.2294 \mathrm{E}-24$ & \\
\hline
\end{tabular}

Source: Authors' own calculation 
Table 8. Details of the t-test results of beneficiaries and the number of transactions at the hand-held machines

\begin{tabular}{|l|c|c|}
\hline \multicolumn{3}{|c|}{ t-Test: Paired Two Sample for Means } \\
\hline Mean & PRE PMJDY & POST PMJDY \\
\hline Variance & 1.18 & 4.355 \\
\hline Observations & 0.14909091 & 0.360075758 \\
\hline Pearson Correlation & 100 & 100 \\
\hline Hypothesized Mean Difference & 0.22277332 & \\
\hline df & 0 & \\
\hline$t$ Stat & 99 & \\
\hline$P(T<=t)$ one-tail & -49.832862 & \\
\hline$t$ Critical one-tail & $3.1609 \mathrm{E}-72$ & \\
\hline $\mathrm{P}(\mathrm{T}<=\mathrm{t})$ two-tail & 1.66039116 & \\
\hline $\mathrm{t}$ Critical two-tail & $\mathbf{6 . 3 2 1 7 E - 7 2}$ & \\
\hline
\end{tabular}

Source: Authors' own calculation

number of transactions through the hand-held device and it is found that the significant value is less than 0.05 , and therefore there is no evidence to reject the alternate hypothesis. Thus, we accept the alternate hypotheses and state that there is a considerable increase in the number of transactions at the hand held device post PMJDY.

\subsubsection{Beneficiaries Approaching Banks for Loans}

Ha: The mean difference of the pre and post PMJDY samples with reference to the BCs observations about the number of people approaching bank for loan products is not zero.

Ho: The mean difference of the pre and post PMJDY samples with reference to the BCs observations about the number of people approaching bank for loan products is zero.

With the awareness level of the beneficiaries and the lack of knowledge because of financial illiteracy, the number of people who would often visit the bank premise for availing various services was very less. However, with increased awareness and financial literacy drives, the beneficiaries are getting informed about the services that they could avail and therefore they are approaching the banks for various requirements. There also are various other initiatives which the banks have introduced specifically for the beneficiaries and because of this there has been an increase in the number of people approaching the banks.

"A Paired Sample t-test was run to test if the means of both the samples is equal and if the mean difference is zero". But on running the test, as per the table 9, it is found that the mean difference is 1.93 which is significantly more than 0 and also the $\mathrm{p}$ value is significantly lower than 0.05 and therefore, we have no reasons to support or accept null hypothesis. We therefore accept the alternate hypothesis and conclude that there is a significant difference between both the means and we conclude that the number of people approaching banks for loans has increased post PMJDY.

\subsubsection{Beneficiaries Approaching the Bank for Parking their Savings}

Ha: The mean difference of the pre and post PMJDY samples with reference to the BCs observations about the number of people approaching bank for savings products is not zero

Ha: The mean difference of the pre and post PMJDY samples with reference to the BCs observations about the number of people approaching bank for savings products is zero

Post the implementation of PMJDY with the different riders added to the rupay card, it has been observed that the money deposited in the savings bank account has been steadily increasing. To know if actually people are forthcoming in using the saving products of banks, this hypothesis was tested.

Upon running the paired sample $\mathrm{t}$ test, as reported in Table 10, it is found that the means of the two samples is not equal but the mean difference is 2.06 . Also, the $\mathrm{p}$ value is 0.000 which is significantly lower than 0.05 and therefore we do not have much support in evidence of the null hypothesis. Therefore, we reject the null hypothesis and accept the alternate hypothesis and state that there is a statistically significant difference 
Table 9. Details of the t-test results of people approaching banks for loans

\begin{tabular}{|l|c|c|}
\hline \multicolumn{3}{|c|}{ t-Test: Paired Two Sample for Means } \\
\hline Mean & PRE PMJDY & POST PMJDY \\
\hline Variance & 2.17 & 4.1 \\
\hline Observations & 0.243535 & 0.797979798 \\
\hline Pearson Correlation & 100 & 100 \\
\hline & 0.144354 & \\
\hline Hypothesized Mean Difference & & \\
\hline df & 0 & \\
\hline$t$ Stat & 99 & \\
\hline$P(T<=t)$ one-tail & -20.1849 & \\
\hline$t$ Critical one-tail & $3.62 E-37$ & \\
\hline $\mathrm{P}(\mathrm{T}<=\mathrm{t})$ two-tail & 1.660391 & \\
\hline $\mathrm{t}$ Critical two-tail & $7.24 \mathrm{E}-37$ & \\
\hline
\end{tabular}

Source: Authors' own calculation

between the means of two samples and we can conclude that the savings habits have increased post PMJDY.

\section{Findings}

The research has been successful in bringing out the following major findings:

Post the launch of PMJDY, there has been a tremendous increase in the number of accounts opened across the country. With increased number of accounts, there is also an increase noted in the number of transactions too. It is also evident that the amount held in newly opened accounts has increased by over $63 \%$ over the last four years which is highly encouraging.

There is also an increase in the number of Rupay cards loaded with benefits issued to the beneficiaries too. Also, a considerable increase has been registered in the number of beneficiaries at the rural, semi urban, urban and metro centres too.

From the perspective of $\mathrm{BCs}$, there has been a considerable improvement in the number of people who are accessing the banking services. This has been statistically proven too through paired two sample $t$ test. Also there has been a significant decrease in the
Table 10. The t-test results of willingness to save at bank

\begin{tabular}{|l|c|c|}
\hline \multicolumn{3}{|c|}{ t-Test: Paired Two Sample for Means } \\
\hline & PRE PMJDY & POST PMJDY \\
\hline Mean & 1.61 & 3.67 \\
\hline Variance & 0.785757576 & 1.273838384 \\
\hline Observations & 100 & 100 \\
\hline Pearson Correlation & 0.122468431 & \\
\hline Hypothesized Mean Difference & 0 & \\
\hline $\mathrm{df}$ & 99 & \\
\hline $\mathrm{t}$ Stat & -15.29266921 & \\
\hline $\mathrm{P}(\mathrm{T}<=\mathrm{t})$ one-tail & $4.05945 \mathrm{E}-28$ & \\
\hline $\mathrm{t}$ Critical one-tail & 1.660391156 & \\
\hline $\mathrm{P}(\mathrm{T}<=\mathrm{t})$ two-tail & $8.1189 \mathrm{E}-28$ & \\
\hline $\mathrm{t}$ Critical two-tail & 1.984216952 & \\
\hline
\end{tabular}

Source: Authors' own calculation

number of people who are accessing the informal sources of finance too. Timely availability of finance for the villagers in the time of need is one of the important features of an inclusive financial system. This is also an observation made by BCs as there is a considerable increase in the number of beneficiaries walking towards banks for their loan requirements.

It has also been observed that the beneficiaries are forthcoming in parking their savings in the BSBD accounts too. There is also an evidence that there is an increase in the number of people who are performing transactions with the $\mathrm{BC}$ through the hand held device. The $\mathrm{BC}$ as such performs the banking services through the hand held device, increase in these transactions means increase in the banking transactions through the $\mathrm{BC}$. Thus there is also increase in banking transactions post PMJDY.

PMJDY with the different kinds of product features and facilities has no doubt been successful in drawing the attention of the beneficiaries who are now willing to experiment with these services or benefits. With the added loan facilities, insurance facilities no doubt the beneficiaries would identify the fact that the loan accounts could be beneficial to them in the long run.

From the perspective of BCs post PMJDY, people are forthcoming in approaching the banks for loans. This by itself is a considerable improvement as far as 
the landscape of financial inclusion is considered as those who were hesitating to approach the banks for any kinds of loans are now approaching the banks for their various loan requirements. Also there has been a considerable improvement in the number of people who are availing different kind of banking services and also there has been a increase in the number of people who are wanting to utilize the banking post PMJDY.

Beneficiaries who otherwise were shying away from approaching the banks for their various banking services like loan products or savings products are now forthcoming in availing the services. With the increased awareness that is being created post PMJDY, there is a definitive increase in the number of people approaching banks for their various needs.

\section{Direction for Further Research}

Though it has been noted that there is a significant improvement in the banking outreach, there is still a lot of work that needs to be put in by the banks and the concerned to ensure that the people actually start using the services. This area of financial inclusion provides a lot of scope for conducting research. With increased accessibility clearly noted, further research could be conducted to know usage of the banking services by the beneficiaries. Also, a study could be conducted to know to what an extent their enhanced banking habits has brought about a change in their social and economic well being too. A study could also be made to understand the issues faced by the BCs while operating in the field and addressing those issues such that the model could be improvised further.

\section{Conclusion and Recommendations}

With the mission mode initiatives being taken up through the Pradhan Mantri Jan Dhan Yojana, there has been an increased awareness created in the minds of the hitherto excluded, who are now forthcoming in availing the different kinds of banking services and also have now started to be a part of formal banking sector. With the population being in the mainstream financial sector, there will be an increased opportunity for the businesses with the increased money being circulated in the economy. With this there will no doubt be a momentum in the otherwise section of that society which was striving hard for accessing money and was being exploited at the hands of the money lenders.

With the increase in the access to financial banking services, the focus now has to shift towards people using the same effectively to their benefit. This can be ensured only when the beneficiaries are given appropriate orientation towards the savings and loan products which would not only make their livelihood comfortable but also sustainable.

The BC model could be made more useful and successful when transactions do happen. One of the way to ensure the actives transactions to occur, it is important that the transfer of social security benefits to the beneficiaries account which further could be facilitated by the BCs. To make the model more successful, there is a need that there is an increase in the number of people who use these services. This would be possible only when more and more people are not only aware of the $\mathrm{BC}$ system, but also aware of the different kinds of services that they can avail from the BCs and also the services they could avail from the banks. This will be possible only with increased and periodical financial literacy drives. Therefore, it is recommended that the banks increase the number of financial literacy drives.

\section{References}

Aynsely, H. (2010). Financial Inclusion and Financial Capability: What's in a Name? Tony Bee Hall

Barua, A., Kathuria, R., \& Malik, N. (2016). The status of financial inclusion, regulation, and education in India. ADBI Working Paper Series No. 568. https://doi. org/10.2139/ssrn.2773949

CRISIL. (2012). CRISIL inclusix an index to measure India's progress on financial inclusion. Mumbai, Mcgraw Hill

Iqbal, B. A., \& Sami, S. (2017). Role of banks in financial inclusion in India. Contaduría y Administración, 62(2), 644-656. https://doi.org/10.1016/j.cya.2017.01.007

Julie. (2013). The relationship between Financial Inclusion and GDP growth in Kenya. Available from: http:/ erepository.uonbi.ac.ke/bitstream/handle/11295/ 
58543/Oruo Financial\%20Inclusion\%20and\%20GDP\% 20Growth\%20.pdf?sequence $=3$

Kamboj. (2014). Financial inclusion and growth of Indian economy: An empirical analysis. The International Journal of Business and Management, 2(9), 175-179.

Kumar, N. (2012). An empirical analysis of financial inclusion across population groups in India Banking: Key driver for inclusive growth. The IUP Journal of Bank Management, 11(1).

Mishra, S. (2015). Micro finance: The catalytic agent of financial Inclusion in India. International Journal of Management And Science, 6(1), 1-13.

Pal, R. (2016). Financial inclusion: Factor that expedites sustainable economic growth. International Educational Scientific Research Journal, 2(8).

Paramasivan \& Ganeshkumar. (2013). Overview of Financial Inclusion in India. International Journal of Management and Development Studies, 2(3), 45-49.
Rajasekaran, N (2018). Including the excluded: The scenario of finanical inclusion in India. IOSR Journal of Business and Management, 20(2), Version VII, 64-69.

Rangarajan, C. (2008). Report of the Committee on Financial Inclusion, Government of India. New Delhi: RBI.

Singh, Anurag, \& Tandon, P. (2013). Financial inclusion in India: An analysis. International Journal of Marketing, Financial Services \& Management Research, 1(6), 41-54.

Verma, Yogesh \& Garg, Priyanka. (2016). Pradhan Mantri Jan Dhan Yojana (PMJDY): A Step towards Eradicating Financial Untouchability: Indian Journal of Finance. 10(1):56. https://doi.org/10.17010/ijf/2016/ v10i1/85845.

Webistes of PMJDY 